\title{
ANALISIS LAJU ALIR SAMPAH DAN EMISI CARBON YANG DIHASILKAN KOTA BANDA ACEH
}

\author{
M. Faisal \\ Jurusan Teknik Kimia, Fakultas Teknik, Universitas Syiah Kuala, \\ Darussalam, Banda Aceh, 23111, Indonesia \\ Email: mfaisal@unsyiah.ac.id
}

\begin{abstract}
Abstrak
Penelitian ini bertujuan untuk menganalisis aliran material/bahan sampah padat yang ada di kota Banda Aceh dengan menggunakan metode Material Flow Analysis (MFA) yang merupakan salah satu instrumen untuk menganalisis laju alir sampah. Sampah kota yang menjadi objek penelitian dibatasi pada jenis sampah organik, plastik dan kertas. Hasil evaluasi menunjukkan bahwa kondisi pengelolaan persampahan yang ada di kota Banda Aceh masih kurang memadai dan memerlukan pengolahan lebih lanjut. Pemilihan sampah dilakukan dilokasi pembuangan akhir di desa kampong Jawa. Sampah daun diolah menjadi kompos, sedangkan sampah plastik dan kertas tidak dilakukan pengolahan. Persentase sampah organik, kertas dan plastik yang dihasilkan kota Banda Aceh masing-masing sebesar 89,1\%;2,5 \%; 0,74 \%. Berat sampah yang dihasilkan oleh Kota Banda Aceh adalah seberat 86057,64 t/bulan dan menghasilkan emisi karbon sebesar 83726,6 t/bulan.
\end{abstract}

Kata kunci: MFA, pengelolaan sampah padat, sampah organik, kertas, plastik, emisi karbon

\begin{abstract}
This research aims to analyze the material flow of solid waste of Banda Aceh city by using Material Flow Analysis (MFA) method. The domestic wastes used in this research are limited to organic waste, plastic and paper. Results show that the solid wastes in Banda Aceh city do not treated well and thus required further treatment process. Wastes are separated at the kampong Jawa waste treatment process. Leaves waste are treated for compost, while no treatment process for plastic and paper wastes. The percentage of organic wastes, paper and plastic produced from Banda Aceh city were 89,1\%; 2,5\%; $0,74 \%$, respectively. Total amount of waste in the city of Banda Aceh is 86057,64 t/month producing carbon emission of 83726,6 t/month.
\end{abstract}

Keywords: MFA, solid waste treatment, organic waste, papers, plastic, carbon emmission

\section{Pendahuluan}

Pertambahan jumlah penduduk, urbanisasi, perubahan gaya hidup dan masyarakat yang semakin konsumtif, ekonomi booming, telah mengakibatkan meningkatnya jumlah timbulan sampah, jenis, dan keberagaman karakteristik sampah sebuah kota [4]. Meningkatnya volume timbulan sampah memerlukan pengelolaan yang memadai dan terorganisir dengan baik. Pengelolaan sampah yang tidak mempergunakan metode dan teknik pengelolaan sampah yang ramah lingkungan selain akan dapat menimbulkan dampak negatif terhadap kesehatan juga akan sangat mengganggu kelestarian dan fungsi lingkungan. Dengan demikian tujuan utama pengelolaan limbah adalah peningkatan kesehatan dan sumber daya alam, menjaga lingkungan, estestika dan faktor ekonomi akibat pengelolaan yang kurang tepat [7].

Untuk menanggulangi pencemaran yang terjadi akibat penumpukan sampah, saat ini dikenal istilah program $3 \mathrm{R}$ yaitu reduce, reuse, dan recycle. Reduce adalah mengurangi jumlah sampah yang akan terbentuk. Reuse yaitu program penggunaan kembali sampah yang sudah terbentuk seperti penggunaan kembali bahan-bahan plastik/kertas bekas untuk bendabenda yang lebih bernilai jual menjadi souvenir, pot bunga, mainan dan sebagainya, sedangkan dalam proses recycle, sampah sebelum digunakan terlebih dahulu diolah ulang. Bahanbahan yang dapat didaur ulang seperti kertas bekas diolah menjadi kertas tisue, amplop souvenir, kartu nama dan lain-lain. Sampah organik yang berasal dari dapur atau pasar dapat didaur ulang menjadi kompos. Proses daur ulang ini juga dapat mengubah sampah menjadi energi panas yang dikenal dengan proses insenerasi.

Sistem pengolahan sampah di Banda Aceh pada saat ini sudah mengalami perubahan dan perkembangan seperti adanya mesin penghancur sampah organik yang ditempatkan di TPA kota 
Banda Aceh, mesin pengolahan sampah seperti dedauanan menjadi kompos, serta para pemulung yang mengambil sampah organik yang bisa di recycle. Namun, selain perkembangan juga terdapat kendala yang dihadapi oleh pemerintah kota Banda Aceh antara lain adalah kesadaran masyarakat terutama pedagang kaki lima yang masih relatif rendah, kurangnya sarana pewadahan sampah, dan terbatasnya jumlah petugas penyuluh sehingga intensitas penyuluhan masih relatif rendah.

Penelitian tentang perhitungan laju alir sampah dan nilai karbon berdasarkan mekanisme pembangunan bersih belum banyak dilakukan di Indonesia, padahal pengetahuan tersebut sangat penting dalam membangun sebuah sistem pengolahan sampah kota berbasis Mekanisme Pembangunan Bersih.

Penelitian ini bertujuan untuk menganalisis jumlah dan komposisi sampah padat yang ada di kota Banda aceh dan mengetahui emisi karbon yang ditimbulkan oleh sampah tersebut.

\section{Teori}

Sampah dapat diklasifikasikan berdasarkan karakterisik kimiawi dan fisik. Karakteristikkarakteristik kimiawi terdiri dari komponenkomponen organik dan anorganik, yang sangat penting untuk memprediksi aplikasi pengomposan (composting) atau konversinya menjadi metana dan etanol. Karakteristik fisik dari sampah sangat ditentukan oleh kepadatan fisik dari materi-materi sampah tersebut. Sampah bisa berwujud padat, cair dan gas. Karakteristik-karakteristik fisik juga mencakup kadar kelembaban dan distribusi ukuran partikel dari komponen-komponennya [8].

\section{Karakteristik Sampah}

Pada dasarnya pengolahan sampah dibutuhkan analisa karakteristik, terdapat beberapa karaketristik sampah yang penting adalah [3]:

a. Kadar kering, kadar basah. Kadar volatil, kadar abu, Nilai kalor, dan lainnya.

b. Kadar kering, menyatakan berat sampah (\% berat sampah asal) setelah kehilangan air pada pemanasan $105^{\circ} \mathrm{C}$. Kadar air (\% berat asal) adalah berat asal dikurangi kadar kering. Pada musim hujan, sampah yang tidak tertutup akan bertambah beratnya, yang akan mempengaruhi pengangkutan dan penanganan lainnya.

c. Kadar volatil, menyatakan banyaknya bagian sampah yang akan hilang (\% berat kering) pada pemanasan $550^{\circ} \mathrm{C}$. Bagian ini dapat menentukan bagian sampah yang akan terdegradasi.

d. Kadar abu, merupakan kadar kering dikurangi kadar volatil. Parameter ini perlu diketahui untuk menentukan bagian sampah yang tidak terbakar (dalam incinerator) yang harus ditangani lebih lanjut dan

e. Nilai kalor, menyatakan banyaknya energi yang dikandung sampah (Kcal/kg kering). Bertambah tinggi nilai kalor, bertambah mudah terbakar.

\section{Material Flow Analysis (MFA)}

Metode Material Flow Analysis (MFA) adalah suatu metode yang menjelaskan tentang aliran suatu sistem dengan cara mengumpulkan dan menggambarkan aliran sistem tersebut. Tujuan dari studi MFA adalah untuk mengukur arus materi yang mengalir dalam proses sehingga dapat digunakan sebagai langkah untuk memberikan masukan atau saran untuk perbaikan model sistem industri. MFA dibuat meliputi seluruh konteks siklus suatu produk, mulai dari ekstraksi sumber daya, pengolahan sumber daya, fabrikasi produk, pemanfaatannya, penggunaan kembali, daur ulang dan pembuangannya.

MFA dilakukan dengan cara mengidentifikasi dan mengkuantifikasi arusarus material dan enery utama yang mengalir dalam proses. Identifikasi dan kuantifikasi arusarus ini merupakan dasar untuk melakukan perubahan terhadap system yang sudah ada. Perubahan system tersebut dilakukan untuk mengurangi dampaknya terhadap lingkungan dengan membuatnya lebih efisien dalam penggunaan sumber daya. MFA dapat mengarahkan sistem untuk meningkatkan kinerjanya dengan penentuan penghitungan limbah yang hilang dalam sistem [5].

MFA adalah prosedur kuantitatif untuk menentukan aliran bahan dan energi melalui sistem yang ekonomis yang menggunakan Input / Output metodologi, termasuk material dan informasi ekonomi. Ini adalah sistem akuntansi yang menangkap jumlah massa, di mana input (ekstraksi + impor), output yang sama ( konsumsi + ekspor + akumulasi + limbah), dan dengan demikian didasarkan pada hukum Termodinamika.

Prosedur ini menggunakan analisis siklus hidup untuk memastikan bahwa semua aliran material dicatat. Penggunaannya dikaitkan dengan berbagai praktek pengembangan bisnis berkelanjutan seperti zero waste, peningkatan produktivitas sumber daya, dan tanggung jawab. Hal ini menunjukkan bahwa analisis ini dapat 
menawarkan solusi praktis berbasis pasar untuk masalah lingkungan. Penekanan pada efisiensi dimana material mengalir berkontribusi terhadap kesejahteraan manusia [6].

\section{Metodologi Penelitian}

Objek penelitian yang dianalisis yaitu jenis sampah organik, plastik dan kertas.

a. Menghitung Persentase Sampah dan Nilai Kalor.

b. Metode Material Flow Analisis (MFA)

Data sampah yang diperoleh dari penduduk dikumpulkan dan dianalisis untuk mengetahui arus materi dari suatu proses sehingga dapat dilakukan sebagai perbaikan model suatu sistem. Pada penelitian ini, data dikumpulkan dari dinas kebersihan dan dari rumah penduduk yang menjadi sampel penelitian.

c. Questioner

Dalam penelitian ini juga dilakukan pengumpulan data dari penduduk dengan membagikan questioner yang terlampir di Lampiran A melalui questioner, dapat diketahui respon masyarakat terhadap pengolahan sampah di Kota Banda Aceh.

d. Sampah yang menjadi bahan penelitian diambil dari beberapa tempat dari masyarakat sebagai sample penelitian yang dikumpulkan dalam 1 tempat, kemudian dipisahkan sesuai dengan jenis sampah dan dihitung berat dalam $\mathrm{kg}$ yang kemudian dipersentasekan secara keseluruhan.

\section{Hasil}

Pengolahan sampah yang dilakukan di Kota Banda Aceh menggunakan metode landfill, dimana sampah yang ada di kota ditimbun pada suatu lahan yang kemudian menghasilkan gas metana, sampah yang ditimbun dilakukan pemisahan terlebih dahulu, seperti kertas, daun atau ranting pohon, dan plastik. Pengolahan yang dilakukan pada sampah kertas yaitu dengan menjual dan mengolah kembali menjadi kertas yang baru. Sedangkan untuk sampah botol plastik dilakukan recycle.

Penanganan sampah yang telah dilakukan adalah pada sampah kertas, botol plastik dan sampah daun, yaitu dengan pembuatan kompos, yang dilakukan dengan menghancurkan dan atau ranting pohon menjadi bubuk kasar yang dapat digunakan untuk kompos. Recycle paper dilakukan pada pabrik pengolahan kertas yang ada di Ulee Kareng, sedangkan untuk botol plastik dilakukan di daerah Aceh Besar. Penanganan sampah yang belum dilakukan adalah sampah kantong plastik, dimana kantong tersebut masih tercampur dengan sampah organik dalam landfill yang ada di TPA, sampah kaca dan logam juga tidak dilakukan penanganan oleh pemerintah kota Banda Aceh, sampah tersebut hanya dimanfaatkan oleh pemulung dengan menjualnya ke agen pengumpulan yang kemudian dijual ke luar kota. Limbah padat yang berbahaya seperti baterai, sisa cat, residu pestisida dan lain-lain seharusnya juga menjadi perhatian pemerintah kota, karena dapat menyebabkan kerusakan permanen pada lingkungan dan kesehatan masyarakat [1,2].

\section{Perhitungan Neraca Massa Sampah Kota Banda Aceh}

Komponen-komponen sampah yang terdapat dari daerah yang ada di Kota Banda Aceh dihitung berdasarkan data yang diperoleh dari DK3 untuk setiap zona, masyarakat dan juga pemulung yang diilustrasikan pada Gambar 1, nilai tersebut diperoleh dari rumus:

$\mathrm{N}=\mathrm{X} \times \mathrm{F}$

Dimana:

$\mathrm{N}=$ Jumlah sampah dari masing-masing dari daerah $(\mathrm{kg})$

$\mathrm{X}=$ Komposisi sampah $(\%)$

$\mathrm{F}=$ Laju alir sampah atau jumlah sampah yang dihasilkan per hari $(\mathrm{kg})$

Energi panas dari tiap-tiap sampah diperoleh dari hasil kalkulasi nilai kalor, dimana nilai kalor tersebut merupakan hasil kali antara kalor spesifik dengan komposisi sampah. Komposisi sampah diperoleh dari hasil perhitungan neraca massa dan data untuk kalor spesifik dari data primer [9], kandungan kalor jenis sampah ditunjukkan pada Tabel 1 .

Tabel 1. Kandungan Kalor Jenis beberapa Sampah [9].

\begin{tabular}{|c|c|c|}
\hline No & Jenis sampah & Kalor jenis $(\mathrm{Kj} / \mathrm{Kg})$ \\
\hline 1 & Sampah makanan & 4.170 \\
\hline 2 & Aneka kertas & 17.530 \\
\hline 3 & Kaca/gelas & - \\
\hline 4 & Plastik & 17.910 \\
\hline 5 & Logam & - \\
\hline 6 & Kayu & 199.401 \\
\hline 7 & Kain/tekstil & 7.720 \\
\hline 8 & Karet & 26.230 \\
\hline 9 & Baterei & \\
\hline 10 & Lain-lain & \\
\hline
\end{tabular}




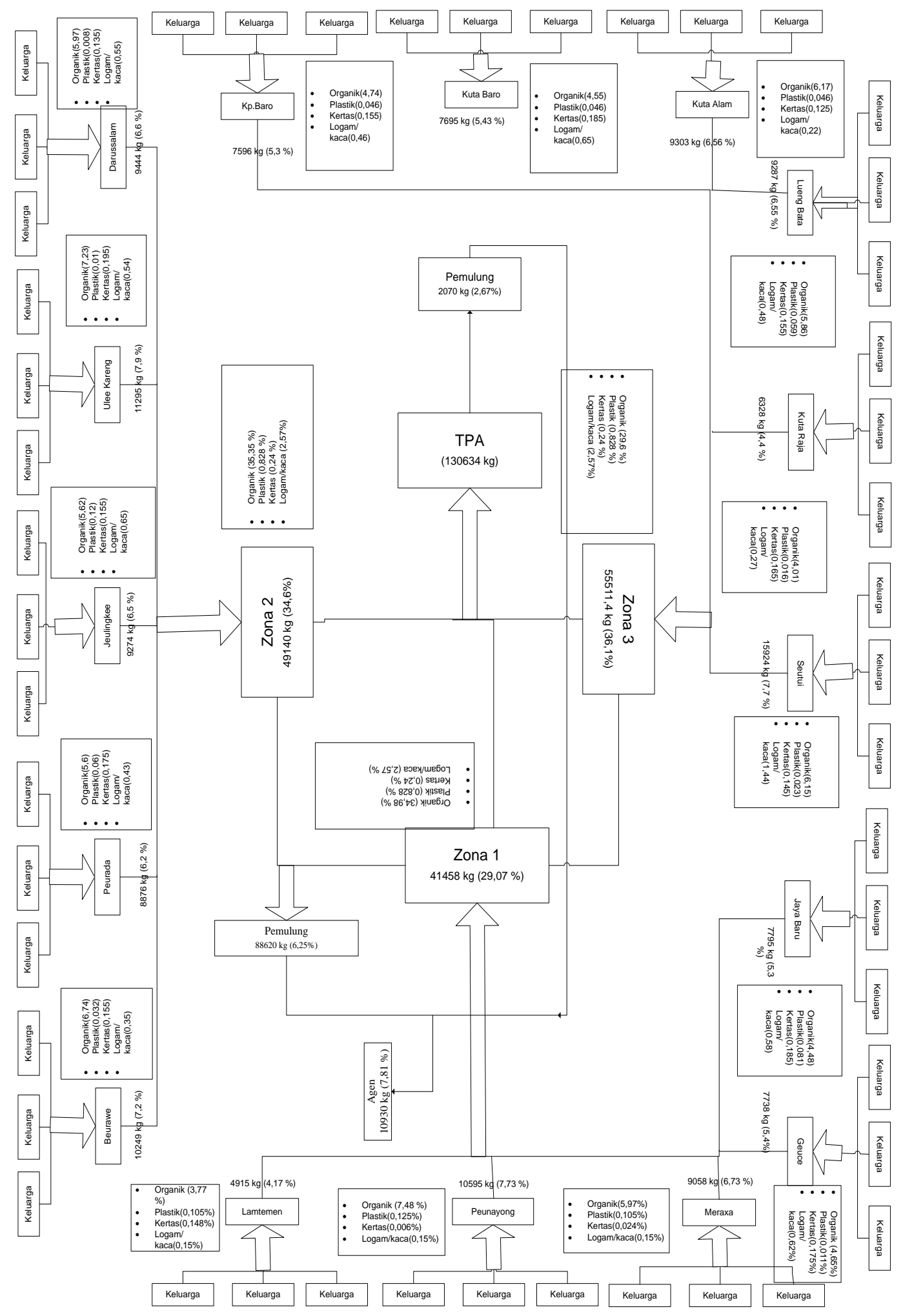

Gambar 1. Neraca Massa Sampah Kota Banda Aceh 
Perhitungan nilai kalor (heating value) dari masing-masing jenis sampah diperoleh dari hasil kali antara kalor jenis dengan persentase kandungan sampah, dengan data kalor jenis yang terdapat pada Tabel 1 dan dari karakteristik sampah kota Banda Aceh yang terdapat dalam Tabel 2. Hasil perhitungan ditabulasikan pada Tabel 3. Berdasarkan hasil perhitungan, jenis sampah kertas memiliki nilai kalor terbesar yaitu 43570,1 kJ/kg dibandingkan dengan sampah makanan dan sampah plastik.

Tabel 2 Berat dan Persentase Sampah Kota Banda Aceh

\begin{tabular}{|c|c|c|c|}
\hline No & Jenis Sampah & $\begin{array}{c}\text { Berat } \\
\mathrm{kg})\end{array}$ & $\begin{array}{c}\text { Persentase } \\
(\%)\end{array}$ \\
\hline 1 & $\begin{array}{c}\text { Sampah } \\
\text { Makanan }\end{array}$ & 126124 & 89,1 \\
\hline 2 & Kertas & 3520 & 2,5 \\
\hline 3 & Plastik & 1050 & 0,74 \\
\hline 4 & Logam/Kaca & 10930 & 7,81 \\
\hline
\end{tabular}

Table 3. Nilai kalor yang terkandung dalam Sampah

\begin{tabular}{|c|c|c|c|c|}
\hline No & $\begin{array}{c}\text { Jenis } \\
\text { sampah }\end{array}$ & $\begin{array}{c}\text { Persent } \\
\text { ase }(\%)\end{array}$ & $\begin{array}{c}\text { Kalor } \\
\text { jenis } \\
(\mathrm{kj} / \mathrm{kg})\end{array}$ & $\begin{array}{c}\text { Nilai } \\
\text { kalor } \\
(\mathrm{kj} / \mathrm{kg})\end{array}$ \\
\hline 1 & $\begin{array}{c}\text { Sampah } \\
\text { makanan }\end{array}$ & 89,1 & 4.170 & $\begin{array}{c}371361, \\
5\end{array}$ \\
\hline 2 & Kertas & 2,5 & 17.530 & 43570,1 \\
\hline 3 & Plastik & 0,744 & 17.910 & 13278,5 \\
\hline
\end{tabular}

\section{Perbandingan Jumlah Sampah Menurut SNI} dan Data Penelitian

Indonesia termasuk negara berpenghasilan sedang. Berdasarkan data SNI negara yang berpenghasilan sedang menghasilkan sampah sekitar 0,5 - 0,9 kg/orang/hari. Berdasarkan data penelitian, diperoleh jumlah sampah yang dihasilkan oleh penduduk kota Banda Aceh 0,58 $\mathrm{kg}$ /orang/hari dengan jumlah penduduk Banda Aceh sebanyak 242943 jiwa.

\section{Prediksi Jumlah Timbulan Sampah}

Kebutuhan lahan suatu TPA ditentukan oleh jumlah timbulan sampah suatu daerah. Timbulan sampah dipengaruhi oleh jumlah penduduk dan produksi sampah harian. Jumlah penduduk harus diperhitungkan sampai beberapa tahun mendatang. Persamaan yang digunakan untuk menghitung jumlah penduduk untuk beberapa tahun mendatang dan total timbulan sampah sebagai berikut.

$$
\mathrm{Pf}=\mathrm{Po}(1+\mathrm{r}) \mathrm{n}
$$

Dimana :

Pf $=$ Proyeksi penduduk kedepan (orang)

$\mathrm{Po}=$ Jumlah penduduk saat ini (orang)

$\mathrm{r}=$ Rata - rata pertambahan penduduk $(\%)$

$\mathrm{n}=(\mathrm{t}$ final $-\mathrm{t}$ sekarang $)$ interval tahun

$\mathrm{t}=$ variasi waktu (tahun)

Total timbulan sampah yang dihasilkan dihitung dengan persamaan sebagai berikut:

$\mathrm{DSd}=$ Pop $\times \mathrm{ppc}$

Dimana :

Pop $=$ Jumlah penduduk (orang)

Ppc $=$ Timbulan sampah per orang per hari $\mathrm{DSd}=$ Total produksi sampah per hari $(\mathrm{kg} / \mathrm{hari})$

Tabel 4. Prediksi Jumlah Penduduk dan Timbulan Sampah Kota Banda Aceh

\begin{tabular}{|c|c|c|}
\hline Tahun & $\begin{array}{l}\text { Jumlah } \\
\text { Penduduk(jiwa) }\end{array}$ & $\begin{array}{l}\text { Jumlah } \\
\text { Sampah(kg) }\end{array}$ \\
\hline 2013 & 258232 & 150536 \\
\hline 2014 & 274483 & 160010 \\
\hline 2015 & 291756 & 170079 \\
\hline 2016 & 310117 & 180782 \\
\hline 2017 & 329633 & 192159 \\
\hline 2018 & 350377 & 204252 \\
\hline 2019 & 372427 & 217106 \\
\hline 2020 & 395864 & 197932 \\
\hline 2021 & 420776 & 210388 \\
\hline 2022 & 447256 & 223628 \\
\hline 2023 & 475402 & 237701 \\
\hline 2024 & 505320 & 252660 \\
\hline 2025 & 537120 & 268560 \\
\hline 2026 & 570921 & 285461 \\
\hline 2027 & 606850 & 303425 \\
\hline 2028 & 645040 & 322520 \\
\hline 2029 & 685633 & 342816 \\
\hline 2030 & 728780 & 364390 \\
\hline
\end{tabular}

Tabel 4 menunjukkan prediksi jumlah penduduk dan jumlah sampah dari tahun 2000 2030 dimana jumlah penduduk kota Banda Aceh dihitung berdasarkan rumus pada pers. 2 dengan nilai $\mathrm{r}=0.062931$. Demikian pula dengan nilai timbulan sampah yang dihasilkan oleh penduduk dihitung berdasarkan rumus pada pers. 3 dengan nilai $\mathrm{Ppc}=0,582949$ yang diperoleh dari hasil pembagian jumlah 
penduduk dengan jumlah sampah yang dihasilkan. Jumlah sampah yang dihasilkan berbanding lurus dengan jumlah penduduk dimana semakin bertambahnya penduduk setiap tahun maka semakin banyak jumlah sampah yang dihasilkan.

\section{Emisi Karbon}

Karbondioksida $\left(\mathrm{CO}_{2}\right)$ merupakan gas yang diperlukan dan berguna bagi keseimbangan alam, tetapi keberadaannya yang tidak seimbang akan membuat fenomena alam yang mampu merusak bumi. Oleh karena itu konsentrasi $\mathrm{CO}_{2}$ yang sesuai harus dipertahankan. Komposisi karbondioksida dalam udara bersih seharusnya adalah 314 ppm. Karbondioksida yang berlebih di udara dapat menimbulkan pengaruh yang tidak baik bagi lingkungan, seperti: merusak lapisan ozon, efek gas rumah kaca, peningkatan suhu permukaan bumi, meningkatkan permukaan air laut, dan lain-lain. Emisi karbon yang dihasilkan oleh Kota Banda Aceh dihitung dengan menggunakan Waste Carbon Calculator dari website www.carbonneutral.com.au [10] dimana dengan berat sampah 86057,64 t/bulan menghasilkan emisi karbon sebesar 83726,6 t $\mathrm{CO} 2$ / bulan. Beberapa studi kasus menunjukkan bahwa sampah kota yang dalam proses pengolahan dan pembuangan, landfill, trasnportasi, dan insenerator merupakan kontributor utama emisi green house gas (GHG) terutama $\mathrm{CO}_{2}$ dan $\mathrm{CH}_{4}$ dan memberikan pengaruh yang sangat besar terhadap perubahan lingkungan $[2,11]$.

\section{Kesimpulan}

1. Sampah yang dihasilkan Kota Banda Aceh terdiri dari: Sampah organik, plastik, kertas, logam/kaca, dan sampah lainnya. Persentase sampah organik, kertas dan plastik yang dihasilkan kota Banda Aceh masing-masing sebesar 89,1\%; 2,5\%; 0,74\%.

2. Berdasarkan data quistioner yang diperoleh, masyarakat kota Banda Aceh masih kurang peduli terhadap pemilahan dan penanganan sampah.

3. Berdasarkan data penelitian, sampah yang diperoleh oleh masyarakat 0,58 $\mathrm{kg} /$ orang/hari.

4. Jumlah Nilai Kalor yang dihasilkan dari sampah organik, plastik dan kertas sebesar $428210,035 \mathrm{kj} / \mathrm{kg}$.

\section{Ucapan Terimakasih}

Terimakasih kepada Lufthiana dan Marhamah Tarmizi atas pengumpulan data dan analisis yang telah dilakukan.

\section{Daftar Pustaka}

[1]. B. Gu, W. Zhu, H. Wang, R.Zhang, M. Liu, Y. Chen, Y.Wu, X.Yang, S. He, R. Cheng, J.Yang, J. Bi, Waste Mana. 34 (2014) 2414.

[2]. H. Lu, S. Sun, L. Ren, L. He, J. Hazard. Mat. 284 (2015) 92.

[3]. Kurniawan, Y. (2010). Pelatihan untuk Peningkatan Pengelolaan Sampah Kabupaten/Kota (P3SK). Dinas Kebersihan dan Keindahan Kota: Banda Aceh.

[4]. L. A. Guerrero, G.Maas, W. Hogland, Waste Mana. 33 (2013) 220.

[5]. Narafumi. 2011. Ekologi Industri. http://narafumiceritapenuhhikmah.blogspot.com/2011_08_ 01_archive.html. diakses pada tanggal 18 Agustus 2011

[6]. Nakamura, S.; Kondo, Y. (2009). Waste Input-Output Analysis. Concepts and Application to Industrial Ecology. Springer.

[7]. R.E. Marshall, K. Farahbakhsh, Waste Mana. 33 (2013) 988.

[8]. Suyitno. 2007.

http://msuyitno.blogspot.com/2007/07/ener gi-dari-sampah-1-pendahuluan.html. diakses pada tanggal 7 Agustus 2011.

[9]. Wiradarma, Rekayasa 3 (2002) 1.

[10]. Website: www.carbonneutral.com.au. diakses pada 16 Agustus 2013.

[11]. Y. Fernandez-Nava, J. del Río, J. Rodríguez-Iglesias, L. Castrillon, E. Maranon, J,Cleaner Prod. 81 (2014) 178. 